\title{
ETHIOPATHOGENESIS, DIAGNOSIS AND THERAPY OF ACQUIRED MEGACOLON IN DOGS
}

\author{
PROKIĆ B*, TODOROVIĆ VERA**, MITROVIĆ OLIVERA**, VIGNJEVIĆ SANJA** \\ and SAVIĆ STEVANOVIĆ VERA* \\ *University of Belgrade, Faculty of Veterinary Medicine, Serbia \\ **University of Belgrade, Institute for Medical Research, Serbia \\ (Received $5^{\text {th }}$ September 2009))
}

Megacolon refers to an abnormal dilatation of the colon. This condition occurs in both humans and animals. Although it seems to be more common in cats, megacolon may also occur in dogs. However, data regarding the etiopathogenesis, clinical course and outcome of canine megacolon are scarce. The aim of this study is to present the experience of our team in diagnosis and therapy of canine acquired megacolon, with particular reference to etiopathogenetic aspects.

The prospective study included 28 dogs affected with megacolon, aged 5-9 years. The 26 animals underwent a surgical procedure (colonotomy followed by manual extraction of faeces), and were followed up for a period of 28 days. On the basis of anamnestic data, clinical and radiographic findings, 7 dogs (25\%) were presented with idiophatic acquired megacolon, while $75 \%$ of cases had secundary acquired megacolon of different etiology (including pelvic canal stenosis, lumbar and sacral spinal injuries or back leg fractures, in $46 \%$ od cases; keeping the animals in the backyard and irresponsibility of their owners, in 11\%; non-adequate nutrition, in 11\%; and decreased physical activity and keeping animals in small flats, in 7\%). During early postoperative period, the medical treatment and dietary regimen enabled defecation in $65 \%$ of cases. The remaining $35 \%$ of cases were treated with Cisapride in order to establish spontaneous defecation. All dogs recovered completely during the 28days follow-up period. According to the results of interviews with dog owners, all animals were in good condition six months after the surgical procedure.

Key words: acquired megacolon, dog, etiology, surgery

\section{INTRODUCTION}

Megacolon is a condition that is uncommonly described in dogs. It refers to an abnormal dilatation of the colon that may be acute, chronic or toxic. Chronic megacolon can be classified as congenital (also known as Hirschsprung's disease in humans) or acquired, and may be either primary or secondary. The 
cause of primary megacolon is unknown, so it is also termed idiopathic. The pathogenesis of idiopathic megacolon is still a subject of controversy, although it has been historically attributed to a primary neurogenic or degenerative neuromuscular disorder (Meier-Ruge et al., 2006). Secondary megacolon can occur as the result of intestinal wall lesions or various conditions that prevent defecation for a prolonged period of time (Bharucha, 1999).

Two pathological mechanisms are implicated in megacolon development: dilatation and hypertrophy. Dilated megacolon represents the end-stage of colonic dysfunction in idiopathic cases. On the other hand, hypertrophic megacolon refers to the functional disorder that develops as a result of chronic obstructive lesions (stenosis of the pelvic canal, tumor, foreign body, etc.) (Washabau and Hasler, 1996).

Diagnosis of megacolon is based on medical history and clinical examination and is confirmed with native radiographs of the abdomen. The patients are usually presented with a history of lethargy, decreased appetite and failure to defecate over a long period of time (Colin, 1995; Gattuso and Kamm, 1997). Clinical examination commonly reveals dehydration, abdominal pain and mild mesenteric lymphadenophaty (Washabau and Hasler, 1996). Complete neurologic examination should be performed in order to identify neurologic causes of constipation, for example, spinal cord injury or nerve trauma. The diagnostic work-up should also include laboratory findings to rule out any metabolic abnormalities. Radiographs can confirm the presence of a large colon and can also be used to determine if there are any old pelvic fractures, masses or spinal deformities. It's important to emphasize that radiographic examination using barium sulfate is usually contraindicated. Taking into consideration that the final diagnosis of megacolon is usually made by excluding all other causes of constipation and/or obstipation, several studies emphasized the importance of differential diagnosis (Burrows, 1991; Washabau and Hall, 1997).

The therapy for megacolon depends on several factors including the severity of constipation and fecal impaction and the underlying cause. The initial treatment is aimed to establish and/or maintains a fluid and electrolyte balance, as well as to eliminate the possible causes of constipation. In addition, medical therapy with stool softeners is the first-line treatment for this condition. In this respect, animals should be appropriately hydrated and then an enema should be performed. Thereafter, medical management with laxatives (Bisacodyl), procinetics (Cisapride) and cathartics (lactulose) should be initiated. Cisapride has been frequently used in the management of the gastric empting disorders, intestinal transit and other motility disorders in both dogs and cats (Wiselman and Faulds, 1994; Washabau, 2003). When medical therapy is no longer effective, surgery is recommended. Although surgery is usually referred to as a subtotal colectomy, in some cases colonotomy with fecal mass removal may also be considered as the treatment of choice (Webb, 1985). Postoperatively, parenteral antibiotic and vitamin therapy should be continued. Prognosis depends on early recognition and management of megacolon (Nemeth et al., 2008).

Megacolon has been widely described in cats and majority of literature data on this condition refers to cats. Megacolon can occur at any age, breed, or sex of 
Acta Veterinaria (Beograd), Vol. 60, No. 2-3, 273-284, 2010.

cat; however, most cases are seen in middle-aged male cats. Although there are few studies describing canine megacolon, data regarding the pathogenesis, clinical course and outcome in this condition are scarce.

\section{MATERIAL AND METHODS}

\section{Animals}

This prospective study included 28 dogs diagnosed with secondary acquired megacolon/ idiopathic megacolon, aged 5-9 years. Over the period 1996-2000, the dogs were examined and treated at the Faculty of the Veterinary Medicine, University of Belgrade.

The group of 28 examined dogs with megacolon consisted mainly of males (21 dogs, 75\%), and most of them was at the age of 8 years (14 dogs, $50 \%$ ). The basic information's on breed, sex and age of examined dogs with megacolon are shown in Table 1.

Table 1. Breed, gender and age of examined dogs with acquired megacolon

\begin{tabular}{|l|c|c|c|c|c|c|c|c|}
\hline \multirow{2}{*}{ Dog breed } & \multicolumn{2}{|c|}{ Gender } & \multicolumn{5}{c|}{ Age (years) } & Number \\
\cline { 2 - 9 } & male & female & 5 & 6 & 7 & 8 & 9 & of dogs \\
\hline \hline German shepherd & 6 & 3 & 1 & - & - & 6 & 2 & 9 \\
\hline Rottweiller & 4 & 1 & - & - & 3 & 2 & - & 5 \\
\hline Giant Schnauzer & 4 & - & - & 1 & - & 2 & 1 & 4 \\
\hline Sharr Mountain dog & 5 & 2 & 1 & 1 & 2 & 2 & 1 & 7 \\
\hline Mix-breed dog & 2 & 1 & - & 1 & 0 & 2 & - & 3 \\
\hline \hline Total & 21 & 7 & 2 & 3 & 5 & 14 & 4 & 28 \\
\hline
\end{tabular}

The diagnosis of megacolon was established on the basis of detailed anamnestic data, clinical examination, abdominal radiographic findings and pathohistological findings. After the diagnosis was established, euthanasia was performed on two animals with very poor health condition. The other animals were subjected to the surgical procedure, and were followed up for a period of 28 days after surgery, until complete recovery.

\section{Preoperative treatment}

Immediately after the diagnosis was established, over a period of 2-3 days, all dogs were subjected to an initial treatment for restoration of their general health condition and for surgical procedure preparation. In order to correct electrolyte and energy imbalance, the animals were treated with infusions of Ringer's lactate solution $(500 \mathrm{~mL}), 5 \%$ glucose solution $(500 \mathrm{~mL})$ and aminosteril solution $(30 \mathrm{~mL})$. In addition, once a day for three days, all animals were treated with preoperative antibiotics and vitamin therapy (penicillin G, 800,000 U i.v.; Vitoligam, $3 \mathrm{~mL}$ s.c.; and vitamin-B complex 3-5 mL s.c.). Before surgery, the animals were 
premedicated with Atropine sulphate (s.c.), Acepromazine (i.v.) and Formidal (s.c.), and then anesthetized with Ketamine hydrochloride (i.v. and i.m.).

\section{Operative procedure}

All animals underwent a median laparotomy and extra-abdominal colonotomy with a longitudally placed incision on the transversal part of the colon, followed by manual extraction of the intestinal contents. Closure of the incision was accomplished by a continuous absorbable, synthetic, braided suture (Vicryl 4-0), followed by a second row interrupted Lembert type suture and standard abdominal closure technique (Vicryl 3-0, 2-0, - peritoneal, muscular, subcutaneous suture; Dexon 2-0 - skin suture).

\section{Postoperative care}

During the early postoperative period (7 days after surgery), antibiotics, electrolyte solutions and vitamin therapy (penicillin G, Ringer's lactate, glucose, aminosteril, vitamin $\mathrm{C}$ and vitamin-B complex) were continued and dogs were closely monitored for infection. The animals were treated with topical iodine preparations and appropriate topical antibiotics in order to prevent a possible wound infection. The plastic collar was placed around the animal's neck to prevent them from licking or biting wounds. The animals were deprived of water for two days after surgery. On the third postoperative day, all animals were given water only $(3 \times 200 \mathrm{~mL})$. In addition to water, for the next three days $\left(4^{\text {th }}-7^{\text {th }}\right.$ postoperative day), animals were fed with chicken or beef soup $(2 \times 200 \mathrm{~mL}$, concentrate). Thus, the daily amount of fluid, given per os, was $1000 \mathrm{~mL}$. During this period, the animals were deprived of solid food. Seven days after surgery, both medicamental and vitamin therapy were interrupted. Starting from the $8^{\text {th }}$ postoperative day, solid food (raw minced beef $2 \times 150 \mathrm{~g}$, and wheat bran $2 \times 50 \mathrm{~g}$, per day) was introduced to the diet and dogs were allowed ad libitum access to water. Skin sutures were removed on the $7^{\text {th }}$ postoperative day, while the protective collar was removed two days later.

During the third postoperative week, in addition to raw beef, fresh bread $(2 \mathrm{x}$ $50 \mathrm{~g}$, per day) was introduced to the diet. After this period, in some animals defecation did not occur. These animals received Cisapride, $10 \mathrm{mg}$ per os, three times a day. Cisapride was discontinued on $21^{\text {st }}$ postoperative day, and all animals were given an incresed amount of food (meat $2 \times 200 \mathrm{~g}$, toasted bread $2 \times$ $50 \mathrm{~g}$, wheat bran $50 \mathrm{~g}$ and soup concentrate $2 \times 200 \mathrm{~mL}$ ). Animals were fed twice a day, during the period of 28 days after surgery. Thereafter, all animals were submitted to clinical and radiographic control examinations. According to control examinations, all animals showed complete recovery and dog owners were advised to feed the animals once a day. The younger dogs were allowed to eat bone six months after surgery, while eating bones was strictly prohibited for older dogs. 
Acta Veterinaria (Beograd), Vol. 60, No. 2-3, 273-284, 2010.

\section{RESULTS}

\section{Diagnostic data}

All 28 dogs (age range: 5 to 9 years; mean age: $7.53 \pm 0.21$ years, median: 8 years) with megacolon were clinically examined. Prior to physical examination, dog owners provided us with anamnestic data. According to medical history, $45 \%$ of dogs were presented with diarrhoea, $35 \%$ with prolonged constipation, and in $10 \%$ of cases the owners reported the assumption that the dog swallowed a foreign body. In some cases (10\%), the owners did not pay attention to the physiological activities of their dogs and the animals were clinically examined for serious deterioration of their general health condition.

The physical examination revealed deterioration in health status, lethargy, significant weight loss, ataxia, bowed body posture (regarding the head and neck position), serous/purulent eye discharge or dry eye, dry skin, loss of skin elasticity and a markedly distended abdomen. Abdominal palpation confirmed the presence of large faecal mass within the colon. Colonic impaction was hard, stone-like consistency on palpation. Abdominal pain and tenderness on abdominal palpation were registered in extremely severe cases (the absence of defecation even up to 60 days). Except for two severe cases, haematological and biochemical blood parameters were within reference ranges. The laboratory findings of these two animals revealed anaemia, hypokalemia and hypocalcaemia. In addition, subfebrile condition and bradicardia were registered in 3 of 28 dogs (8.1\%).

Abdominal radiography of all examined dogs showed colonic distension with stool retention. Markedly dilated colon with a diameter up to $20-30 \mathrm{~cm}$ was evident on all radiographic images (Figure 1). In most cases, enlarged colon extended from the epigastric region to the pelvic canal.

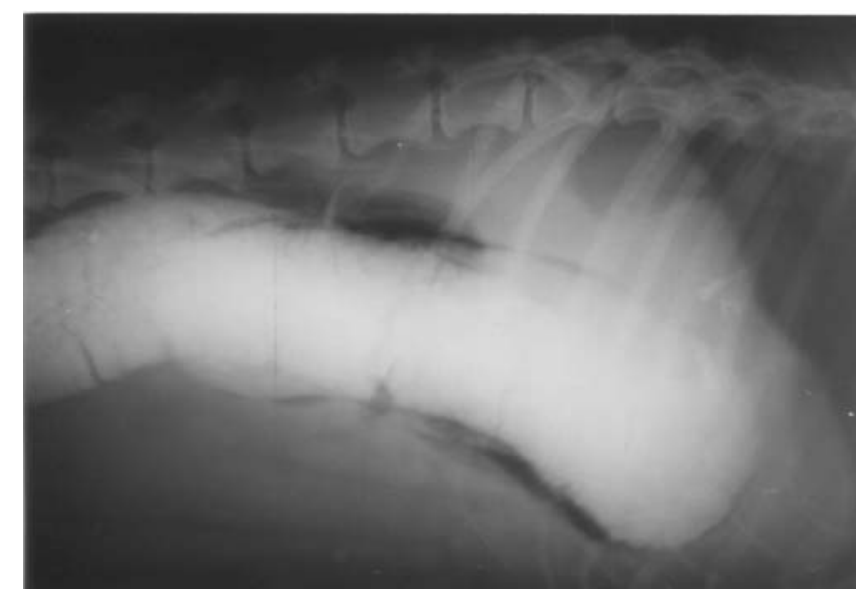

Figure 1. Radiographic image of markedly dilated colon in a dog with idiopathic megacolon 
Based on anamnestic data, clinical and abdominal X-ray findings, in 7 of 28 dogs $(25 \%)$ the cause remained unknown, and those cases were classified as idiopathic acquired megacolon. Medical history, clinical and radiographic findings of remaining animals with secondary acquired megacolon revealed that in $7 \%$ of cases the possible cause was decreased physical activity and keeping animals in small flats, while in $11 \%$ the predisposing factor was keeping the animals in the backyard and irresponsibility of their owners. Additionally, nonadequate nutrition was a possible cause of megacolon in $11 \%$ of cases, while 13 animals (46\%) had both clinical and radiographic signs of pelvic canal stenosis, lumbar and sacral spinal injuries or back leg fractures (Figure 2). There was no difference in the age distribution of these predisposing factors. However, at the age of 5 years no case with the above mentioned predisponing factors was registered (Table 2 ).

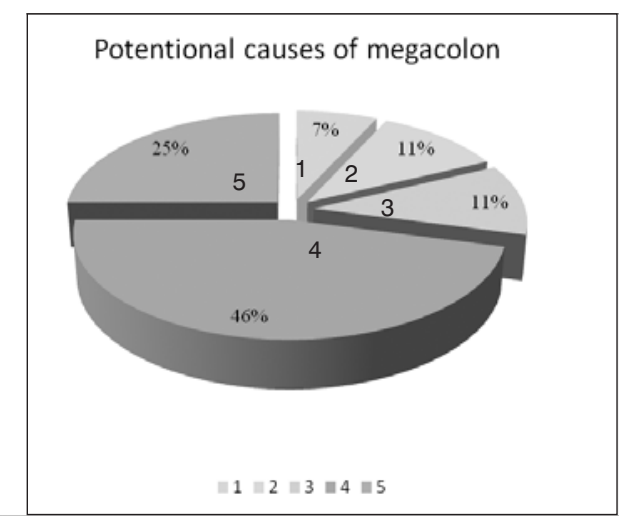

Figure 2. Distribution of potentional etiological factors of megacolon

1. Decreased physical activity and keeping the animals in small flats;

2. Keeping the animals in the backyard and irresponsibility of their owners:

3. Non-adequate nutrition;

4. Pelvic canal stenosis, lumbar and sacral spinal injuries or back leg fractures;

5. Idiophatic acquired megacolon

Table 2. Predisposing factors for the development of megacolon - age distribution

\begin{tabular}{|c|c|c|c|c|c|}
\hline \multirow{2}{*}{$\begin{array}{c}\text { Age } \\
\text { (years) }\end{array}$} & $\begin{array}{c}\text { Decreased activity/ } \\
\text { keeping dogs in } \\
\text { small flats }\end{array}$ & $\begin{array}{c}\text { Negligence of } \\
\text { dog owners / } \\
\text { keeping the dogs } \\
\text { in backyards }\end{array}$ & $\begin{array}{c}\text { Non- } \\
\text { adequate } \\
\text { nutrition }\end{array}$ & $\begin{array}{c}\text { LSS* injuries/ } \\
\text { leg fractures }\end{array}$ & Unknown \\
\hline \hline 5 & - & - & - & - & 2 \\
\hline 6 & - & 1 & 1 & - & 1 \\
\hline 7 & - & 2 & - & 3 & 1 \\
\hline 8 & 2 & - & 1 & 8 & 2 \\
\hline 9 & - & - & 1 & 2 & 1 \\
\hline \hline $\begin{array}{c}\text { Total } \\
\text { number }\end{array}$ & 2 & 3 & 3 & 13 & 7 \\
\hline
\end{tabular}

*LSS - lumbosacral spine 
Acta Veterinaria (Beograd), Vol. 60, No. 2-3, 273-284, 2010.

Surgical findings and postoperative treatment results

Following a ventral midline laparotomy, the intraoperative diagnosis of megacolon was established based on the presence of a markedly dilated colon, filled with hard faecal masses. Subsequently, the longitudinal colonotomy with manual extraction of faeces was performed. Some details regarding the surgical intervention are shown in Figure 3.

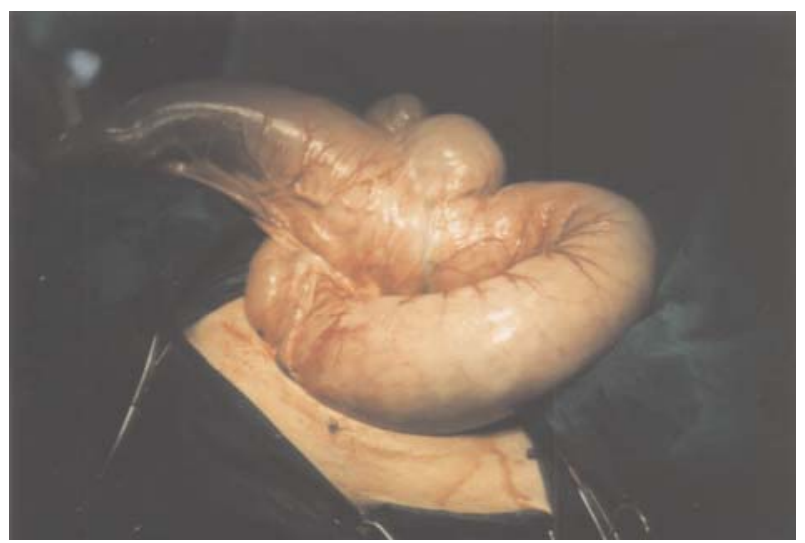

Figure 3. Gross apearance of megacolon before colonotomy followed by manual extraction of faeces

During colon surgery, full thickness tissue specimens from the dilated transversal colon were taken for pathohistological examination. Pathohistological findings of all tissue specimens, including immunohistochemical findings of enteric nervous system and VIP-eregic innervation of affected colon segment were presented in our previous report (data not shown) (Prokic et al., 2009).

No intraoperative complications were observed. The medical treatment during early postoperative period ( $1-7^{\text {th }}$ postoperative day), followed by gradual introduction of solid foods $\left(7^{\text {th }}-14^{\text {th }}\right.$ postoperative day) enabled defecation in $65 \%$ of cases. The remaining $35 \%$ operated dogs were treated with Cisapride in order to establish a regular defecation. Thus, the complete recovery of all operated dogs with megacolon was evident during the 28-day postoperative period. According to the data obtained from dog owners, all animals were in good condition six months after the surgical procedure.

\section{DISCUSSION}

Megacolon is a condition that occurs in both humans and animals. This condition seems to be more common in cats, but may also occur in dogs. However, the exact incidence and prevalence of canine megacolon are unknown. Considering a small number of publications dealing with canine megacolon, usually in case report forms, majority of literature data originates from the numerous studies referring to the feline megacolon. 
It was previously thought that megacolon commonly affects older cats. However, recent studies show that both feline and canine megacolon may be seen at any age (Washabau and Hall, 1997b). According to a review of 120 cases published in English veterinary literature, most cases of megacolon are observed in middle-aged, male cats $(70 \%)$. These data also suggest that megacolon commonly affects domestic shorthair (46\%), domestic longhair (14\%) and Siamese breeding (Washabau and Hasler, 1996).

In cats the disease is characterised by repeated episodes of constipation or prolonged obstipation that may result in complete absence of defecation. Affected cats are presented with anorexia, dehydration, weight loss, vomiting, and lethargy. Occasionally, chronically constipated cats have intermittent episodes of diarrhea. Cats affected with idiopathic dilated megacolon usually have a history of recurrent constipation culminating in obpstipation. On the contrary, animals affected with hypertrophic megacolon usually have a history of automobile or other trauma (Burrows, 1996; Washabau and Holt, 1999).

An extensive list of differential diagnosis for the obstipated cat includes numerous factors associated with a prolonged constipation, such as: neuromuscular, mechanical, metabolic, endocrine, inflammatory, and environmental factors. Although in some cases differential diagnosis may be of critical importance the majority of cases of obstipation are accounted for idiopathic megacolon (62\%), pelvic canal stenosis $(23 \%)$, nerve injury $(6 \%)$ or Manx sacral spinal cord deformity (5\%). In addition, in a small number of cases, obstipation was a result of complications of colopexy (1\%) or colonic neoplasia (1\%), while hypoganglionosis / aganglionosis was suspected in $2 \%$ of cases, but not proven (Washabau and Hasler, 1996; Washabau and Hall, 1997). However, the importance of differential diagnoses for the obstipated dog is not well documented.

In the present study, 28 dogs affected with megacolon, aged 5-9 years, were examined and 26 of them were surgically treated for this condition. To the best of our knowledge, there is no published data referring to canine megacolon that involves such a large number of subjects. On the basis of anamnestic data, clinical and radiographic findings, 7 dogs (25\%) were presented with idiopathic aquired megacolon, while $75 \%$ of cases had secondary acquired megacolon of different etiology.

The results of our study concerning the breed, age and gender of examined dogs are in accordance with literature data showing that both feline and canine megacolon occurred in animals of any age or breed, but they are often seen in middle-aged male animals. The common causes of obstipation are well described in veterinary literature. However, data referring to etiology and pathogenesis of megacolon are very scarce. Data on potential etiological factors, obtained in the present study, are not entirely consistent with previously reported data regarding feline obstipation. In the present case series, nearly half of these cases developed megacolon secondary to lumbosacral spine injuries or leg fractures (13/28 dogs, $46 \%$ ), while in $25 \%$ of cases the cause remained unknown and these cases were classified as idiopathic acquired megacolon. The differences in distribution of etiological factors, between data obtained in our study and literature data, are 
probably due to the fact that obstipation and megacolon are not the same entity, as well as to species differences and the sample size. Some authors emphasized the role of environmental/ behavioral factors in colonic motility disorders (Nemeth et al., 2008; Zoran, 2008). Data obtained in the present study showing that $28 \%$ of examined dogs with megacolon had environmental and behavioural underlying causes are consistent with the emphasized role of these factors in veterinary literature.

Some guidelines were used in establishing the diagnosis of megacolon in humans (Berens et al., 1986; Basilico et al., 1997). Similarly to humans, the diagnosis of canine megacolon is based on detailed anamnesis, physical examination with special regard to abdominal palpation and rectal examination, as well as on abdominal radiography and histopathological findings of colon biopsies. The results of the present study confirmed the diagnostic significance of detailed anamnestic data obtained by dog owners. Detailed anamnesis revealed lethargy, anorexia, frequent vomiting and diarrhea, which are the symptoms commonly described in these patients. Interestingly, the majority of dog owners reported that diarrhea was the main symptom of the disease. In fact, diarrhea was a result of the mucosal irritant effect of dehydrated faeces. Clinical findings of 28 dogs, included in this study, were fairly consistent with the findings described by other authors (Burrows, 1996; Washabau and Stalis, 1996).

All dogs included in this study had normal laboratory findings, except two severe cases. Laboratory findings within the normal reference range rule out metabolic and endocrine underlying causes. The present study confirmed the crucial importance of radiographic findings in the diagnosis of megacolon. Plain abdominal radiography revealed a pathognomonic sign of megacolon (abnormally dilated colonic section filled with hard faeces) in all examined dogs. In the present case series, a grossly dilated colon extended from pelvis to epigastrium causing the displacement of abdominal organs. However, radiographic findings of colonic impaction cannot be used to distinguish between constipation, obstipation and megacolon in idiopathic cases (Washabau and Hall, 1997b). In our case series, the diagnosis of idiopathic cases was supported by histopathological findings. In addition, immunohistochemical findings showed the alterations of VIP-ergic innervation in affected colon segments, more severe in idiopatic subjects, as we have previously reported (Prokić et al., 2008).

The goal of treatment is to maintain a soft stool and to improve colonic motility. In this respect, stimulant laxatives and procinetics are usually administered initially. Recent studies confirmed that feline megacolon is characterized by a generalized dysfunction of colonic smooth muscle, and that treatments aimed at stimulating colonic smooth muscle contraction might improve colonic motility (Washabau and Stalis, 1996). Thus, treatment with the procinetic drug Cisapride can improve the propulsive motility of the gastrointestinal organs, including the colon (Summers and Flatt, 1988; Cucchiara, 1996; Hasler and Washabau, 1997). Cisapride (substituted piperidinyl benzamide) is a gastroprokinetic agent which acts as a serotonin 5-HT4 receptor agonist (Mine et al., 1997). In animal practice it is usually recommended that Cisapride should be given orally at dose of $0.1-0.5 \mathrm{mg} / \mathrm{kg}$, every $8-12 \mathrm{~h}$ (Orihada 
and Sarma, 1994). It is shown that some cases of megacolon respond poorly to medical therapy. In these patients, surgery is a treatment of choice. Surgical intervention is also recommended with persistent colonic dilatation and associated complications. However, it is important to emphasize that there are many treatment options and the most successful therapy usually involves a combination of treatment interventions.

All dogs included in our study underwent colon surgery followed by an intensive postoperative medical treatment. Several surgical techniques for the management of feline idiopathic megacolon have been described, including coloplasty and partial or subtotal colectomy (White, 2002). The current goldstandard surgical treatment of feline idiopathic megacolon is subtotal colectomy (Colopy-Poulsen, 2005). In a recent study Nemeth et al. reviewed the clinical data of eight dogs treated by subtotal colectomy for acquired hypertrophic megacolon during a 5-year period (Nemeth et al., 2008). Their results emphasised the longterm effectiveness of subtotal colectomy with preservation of the ileocolic junction. This procedure involves the removal of a large portion of the colon and only a short distal colonic segment is spared to allow anastomosis. However, some authors demonstrated that the entire colon is likely histologically affected and any amount of colon remaining following subtotal colectomy may continue to dilate, potentially resulting in recurrence of clinical signs (White, 2002). Thus, failure to resects a significant length of grossly normal-appearing colon may result in therapeutic failure. In the present study we performed a colonotomy with manual extraction of faeces in order to avoided a potential therapeutic failure as well as to reduce the rate of both intraoperative and postoperative complications.

Postoperativelly, a combination of dietary regiment and intensive medical treatment with antibiotics and vitamin therapy resulted in defecation in the majority of cases. Cisapride treatment in remaining $35 \%$ of cases improved the propulsive motility of colon and enabled spontaneous defecation. Diet was also an important part of postoperative treatment. Constipated patients are usually fed a standard diet high in fiber to help attract water to the stool, improving its consistency (Foxx-Orenstein et al., 2008). Consumption of high-fiber foods contributes to optimal surgery outcome and helps to prevent postoperative constipation. Starting after the first postoperative week, all dogs included in our study were fed with wheat bran, which is a natural source of fiber. All 26 operated dogs affected with megacolon (19 with secondary and 7 with idiopathic) recovered completely during the follow-up period. According to the results of telephone interviews with dog owners, all animals were in good condition six months after the surgical procedure.

In conclusion, our results show the long-term effectiveness of colonotomy with manual extraction of retained faeces in combination with intensive postoperative treatment in canine megacolon. 
Adress for correspodence:

Dr Branislav Prokić

Universty of Belgrade

Faculty of Veterinary Medicine

Clinic of Veterinary Surgery

Bulevar Oslobodjenja 18

11000 Beograd

E-mail: proka@vet.bg.ac.rs

\section{REFERENCES}

1. Basilico G, Valio P, Bianchi $P A, 1997$, Oesophageal manometry in the evaluation of megacolon with onset in adult life, Gut, 40, 188-91.

2. Berens PRH, Lennard-Jones JE, Hawley PR, Todd IP, 1986, Hirschpung's disease and idiophatic megacolon in adults and adolescents, Gut, 27, 534-41.

3. Bharucha AE, Philips SF, 1999, Megacolon: acute, toxic, and chronic, Curr Treat Options Gastroenterol, 2, 517-23.

4. Burrows CF, 1991, Constipation, obstipation and megacolon, In August JR (ed): Consultacion in Feline Internal Medicine, WB Saunders, Philadelphia, 445.

5. Burrows CF, 1996, Constipation, obstipation and megacolon in the cat, Waltham Internat Foc, 6, 914.

6. Colin D, Lebastard N, 1995, Pressure sore in patients with spinal cord injuries, Rev Pra, 45, 2023-8.

7. Colopy-Poulsen SA, Danova NA, Hardie RJ, Muir P, 2005, Managing feline obstipation secondary to pelvic fracture, Compend Contin Educ Pract Vet, 27, 662-70.

8. Cucchiara S, Salvia G, Borrelli O, Ciccimarra E, Grasso R, Rapagiolo S, 1996, Severe chronic constipation: limitations of medical therapy and indications for surgical intervention (diagnostic and therapeutic), Pediatr Med Chir, 18, 423-6.

9. Foxx-Orenstein AE, McNally MA, Odunsi ST, 2008, Update on constipation: one treatment does not fit all, Cleve Clin J Med, 75, 813-24.

10. Gattuso JM, Kamm MA, 1997, Clinical features of idiopathioc megarectum and idiopathic megacolon, Gut, 41, 93-9.

11. Hasler AH, Washabau RJ, 1997, Cisapride stimulates contraction of idiopathic megacolonic smooth muscle in cats, $J$ Vet Inter Med, 11, 313-8.

12. Meier-Ruge WA, Müller-Lobeck H, Stoss F, Bruder E, 2006, The pathogenesis of idiopathic megacolon, Eur J Gastroenterol Hepatol, 18, 1209-15.

13. Mine Y, Yoshikawa T, Oku S, Nagai R, Yoshida N, Hosoki K, 1997, Comparison of effect of mosapride citrate and existing 5-HT4 receptor agonists on gastrointestinal motility in vivo and in vitro, $J$ Pharmacol Exp Ther, 283, 1000-8.

14. Nemeth T, Solymosi N, Balka G, 2008, Long-term results of subtotal colectomy for acquired hypertrophic megacolon in eight dogs, J Small Anim Pract, 12, 618-24.

15. Orihata M, Sarna SK, 1994, Contractile mechanism of action of gastroprocinetic agents: cisapride, metoclopramide, and domperidone, Am J Physol Gastrointest Liver Physol, 266, G665-76.

16. Prokić B, Todorović V, Drndarević N, Vignjević S, Đikić D, Nikolić I et al., 2008, Idiopathic and secondary acquired megacolon in dogs is associated with diminished vasoactive intestinal polypeptide innervation of the affected colon, Acta Vet, 59, 53-68.

17. Summers RW, Flatt AJ, 1988, A comparative study of the effects of four motorstimulating agents on canine jejunal spike bursts. The use of a computer program to analyze spike burst spread, Scand J Gastroenterol, 23, 1173-81.

18. Washabau RJ, Hasler AH, 1996, Constipation, obstipation and megacolon. In: Consultations in Feline Internal Medicine, 3rd, August JR (ed), WB Saunders Co, Philadelphia, Chapter 15, 10413.

19. Washabau RJ, Stalis IH, 1996, Alterations in colonic smooth muscle function in cats with idiopathic megacolon, Am J Vet Res, 57, 580-7. 
20. Washabau RJ, Hall JA, 1997, Diagnosis and management of gastrointestinal motility disorders in dogs and cats, Compend Contin Educ Pract Vet, 19, 721-37.

21. Washabau RJ, Holt $D, 1999$, Pathogenesis, diagnosis and therapy of feline idiopathic megacolon, Vet Clin North Am Small Anim Pract, 29, 589-603.

22. Washabau RJ, 2003, Gastrointestinal motility disorders and gastrointestinal prokinetic therapy, Vet Clin North Am Small Anim Pract, 33, 1007-28.

23. Webb SM, 1985, Surgical management of acquired megacolon in cat, J Small Anim Pract, 26, 399405.

24. White RN, 2002, Surgical menagment of constipation, J Fel Med Sur, 4, 129-38.

25. Wiselman LR, Faulds D, 1994, Cisapride. An updated review of its pharmacology and therapeutic efficacy as a prokinetic agent in gastrointestinal motility disorders, Drugs, 47, 116-52.

26. Zoran DL, 2008, Nutritional management of feline gastrointestinal diseases, Top Comp Anim Med, 23, 200-6.

\title{
ETIOPATOGENEZA, DIJAGNOZA I TERAPIJA STEČENOG MEGAKOLONA PASA
}

\author{
PROKIĆ B, TODOROVIĆ VERA, MITROVIĆ OLIVERA, VIGNJEVIĆ SANJA \\ i SAVIĆ STEVANOVIĆ VERA
}

\section{SADRŽAJ}

Megakolon označava abnormalnu dilataciju kolona. Javlja se i kod ljudi i kod životinja. lako je oboljenje češće kod mačaka, javlja se i kod pasa. Međutim, podaci o etiopatogenezi, kliničkom toku i ishodu bolesti megakolona kod pasa su oskudni. Stoga je cilj ove studije da se iznesu sopstvena iskustva o dijagnostici i terapiji stečenog megakolona kod pasa, sa posebnim naglaskom na etiopatogenetski aspekt oboljenja.

Studija je bila prospektivnog karaktera i obuhvatila je 28 pasa sa megakoIonom, starosti 5-9 godina. Dvadeset šest životinja podvrgnuto je hirurškoj intervenciji (kolonotomija sa manuelnom ekstrakcijom fecesa) i praćeno postoperativno u toku 28 dana. Na osnovu anamnestičkih podataka dobijenih od vlasnika pasa, kliničkog i radiografskog nalaza, 7 pasa (25\%) imalo je idiopatski stečeni megakolon, dok je kod 21 psa (75\%) bolest okarakterisana kao sekundarni stečeni megakolon uzrokovan različitim etiološkim faktorima (uključujući stenozu pelvičnog kanala, oštećenje lumbalne i sakralne kičme ili frakturu zadnjih ekstremiteta, kod $46 \%$ pasa; čuvanje životinja u dvorištu i nedovoljni nadzor od strane vlasnika, kod 11\%; neadekvatna ishrana, kod 11\%; smanjenja fizičke aktivnosti i čuvanje životinja u skučenom prostoru, kod 7\%). U ranom postoperativnom periodu, terapija i režim ishrane doveli su do uspostavljanja defekacije kod $65 \%$ pasa. Kod preostalih 35\% slučajeva spontana defekacija je uspostavljena primenom terapije Cisapridom. Sve životinje su se u toku 28-dnevnog nadzora kompletno oporavile, a odlično opšte stanje zabeleženo je, na osnovu intervjua sa vlasnicima i 6 meseci nakon hirurške intervencije. 